\title{
Green Tobacco Sickness: A Review
}

\section{PUJA BHARTI*1, PRERNA ${ }^{1}$, RAHUL RANA ${ }^{1}$, GUNJAN SAINI ${ }^{1}$, NEERAJ $^{1}$}

It is still an unknown fact among many that tobacco harvesters are at a potential at a risk of suffering from "Green Tobacco Sickness (GTS)", with its prevalence seen mostly among Asian and South American tobacco harvesters. These harvesters working in hot, wet conditions are likely to develop GTS, as in such climatic conditions, the wetness and high humidity causes nicotine to reside on the surfaces of the leaves, while the high ambient temperature increases skin absorption, thereby increasing plasma nicotine concentrations by $30-45 \%$. Patients suffering from GTS report nausea, vomiting, pallor, dizziness, headaches, increased perspiration, chills, abdominal pain, diarrhea, increased salivation, prostration, weakness, cough with or without expectoration, breathlessness and occasional reduction in blood pressure or heart rate. GTS is self-limiting and of short duration and hence treatment is not always necessary and not often sought by the harvesters. This review educates readers about GTS as well as encourages their participation in making tougher regulations in their respective countries for the control of this disease.

\section{INTRODUCTION}

Contrary to human beliefs, it is not only the tobacco user who is at a risk of suffering from health consequences. It is also known to many that exposure to second hand smoke also can lead to various health ailments. Even lesser is known about "Green Tobacco Sickness (GTS)", a condition mainly affecting tobacco harvesters with its prevalence seen among in Asian and South American tobacco harvesters. ${ }^{1}$

Handling uncured tobacco through skin contact is toxic, with GTS first reported among tobacco workers in Florida (1970), initially diagnosed as "cropper sickness." In due course of time, its causation was revealed to be the absorption of nicotine from wet tobacco plants and it was subsequently diagnosed as GTS. ${ }^{2}$ It is an acute form of nicotine toxicity, usually occurring few to several hours after a continued exposure to green tobacco leaves during processing.

Nicotine has a low-molecular weight substance with a good lipid and water solubility which is easily absorbed via skin. ${ }^{3}$ This sickness is not well documented and is often underreported due to the fact that those who experience GTS are not able to correctly interpret their symptoms or its cause. Although GTS has not been associated with mortality and/or longterm morbidity, it leads to significant discomfort and lost productivity among tobacco workers, apart from loss of pay for the time/day(s) not spend harvesting tobacco. ${ }^{4}$

Reports state India as the third country to have reported GTS among tobacco harvesters. In India, the bidi industry is the largest manufacturer of tobacco and its manufacture has provided employment to millions of people. Laborers working in hot, wet conditions are more likely to develop GTS, and the Indian climatic conditions are mostly hot and humid in nature. In such climatic conditions, the wetness and high humidity causes nicotine to reside on the surfaces of the leaves, while the high ambient temperature increases skin absorption, thereby increasing plasma nicotine concentrations by $30-45 \% .{ }^{1}$

\section{SYMPTOMS}

Patients suffering from GTS report nausea, vomiting, pallor, dizziness, headaches, increased perspiration, chills, abdominal pain, diarrhea, and increased salivation, prostration, and weakness, depending on the exposure, but are of short duration..$^{5-7}$ These symptoms are neurological in nature. Other symptoms include cough with or without expectoration, breathlessness and occasional reduction in blood pressure or heart rate. ${ }^{8,9}$ Among those susceptible to GTS, the average length of the illness including treatment lies between 1 and 3 days $($ median $=2.4$ days $) .{ }^{10}$

(c) Puja Bharti et al. This is an open access article distributed under the terms of the Creative Commons Attribution License CC-BY-NC 4.o, which permits unrestricted use, distribution and reproduction in any medium, provided the use is not commercial and the original author(s) and source are cited. Submitted on: 24-Sep-2021; Accepted on: 03-Dec-2021 
Among patients, nausea and faintness can occur within 15 minutes of skin contact, although the CDC reports a median time from exposure to onset of GTS as 10 hours (range: 3 to 17 hours).2 Symptoms of GTS are similar in comparison to induced by pesticide exposure and/or heat exhaustion as well as nicotine intoxication experienced by novice smokers and hence, it has a tendency to be misdiagnosed by practitioners unfamiliar with this condition.

\section{PREVENTION}

The main precaution to prevent GTS is to avoid handling of wet tobacco by avoid working in tobacco fields during or immediately after a rainfall and delay work hours until dew has dried. It is also advised to wear protective clothing (e.g., PPE kit, chemical resistant gloves or rain gear) when working with wet tobacco plants; and change into dry clothing as soon as possible if clothing becomes wet. ${ }^{8}$ The simple act of washing hands has been reported to reduce the amount of nicotine on skin by $96 \%$.

Precautions are not only to be practised by the tobacco workers, their employers need to take proactive measures like promoting a safe working environment, discussing routes of exposure and symptoms associated with the disease. They should advise and emphasise workers to change into clean, dry clothing and boots during the work day if these become wet as well as and allow flexible work hours.

\section{TREATMENT}

Workers have reported that a combination of tea and jaggery coupled with rest, was an effective way to cure the symptoms. Due to the nature of GTS being self-limiting and of short duration, treatment is not always necessary and not often sought by the harvesters.

Workers experiencing GTS symptoms are encouraged to increase fluid intake, ingest dimenhydrinate (Dramamine), and rest. Dimenhydrinate is useful in treating GTS once onset has occurred as well as a prophylactic measure before harvesting tobacco. In the event that the symptoms need immediate attention, physicians can administer intravenous hydration, anti-emetics, and Hi blockers (dimenhydrinate). ${ }^{2}$

\section{CONCLUSION}

This review is an attempt to educate readers about GTS, especially in countries like China, Brazil, India, and Malawi which collectively produce more than $60 \%$ of the world's tobacco. ${ }^{13}$

Due to hot and temperate climates, few workers in India and Kentucky reported it being impractical and uncomfortable to wear the recommended protective clothing and hence, there needs to be additional

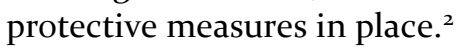

As most of the cases come in light when the patient presents oneself to the clinic, ${ }^{14}$ coupled with selflimiting nature of this disease, most cases go unnoticed. Therefore efforts are required to educate workers and their employers practicing tobacco farming.

\section{REFERENCES}

1. Fotedar S, Fotedar V. Green Tobacco Sickness: A Brief Review. Indian J Occup Environ Med. 2017;21(3):101-4.

https://doi.org/10.4103/ijoem.IJOEM_16o_17.

2. McBride JS, Altman DG, Klein M, White W. Green tobacco sickness. Tob Control. 1998;7:294-8.

3. Vanakoski J, Seppala T, Sievi E, Lunell E. Exposure to high ambient temperature increases absorption and plasma concentrations of transdermal nicotine. Clin Pharmacol Ther. 1996;60:308-15.

4. Singh JK, Rana SVS, Mishra N. Occupational Health Problems Amongst Women Beedi Rollers in Jhansi, Bundelkhand region, Uttar Pradesh. J. Ecophysiol. Occup. Hlth. 2014; 14: 17-22.

5. Ghosh SK, Parikh JR, Gokani VN, Rao MN, Kashyap SK, Chatterjee SK. Studies on occupational health problems in agricultural tobacco workers. J Soc Occup Med. 1980;29:113-7.

6. Boylan BB, Brandt V, Muehlbauer Auslander M, Spurlock C. Green tobacco sickness in tobacco harvesters-Kentucky, 1992. MMWR. 1993;42:23740.

7. Gehlbach SH, Williams WA, Perry LD, Woodall JS. Green-tobacco sickness: An illness of tobacco harvesters. JAMA. 1974;229:1880-3.

8. Ballard T, Ehlers J, Freund E, Auslander M, Brandt $\mathrm{V}$, Halperin W. Green tobacco sickness: Occupational nicotine poisoning in tobacco workers. Arch Environ Health. 1995;50:384-9.

9. Edmonson WD, Smith BD, Morgan HJ. Green tobacco sickness (bradycardia in a young farmer) $\mathrm{J}$ Tenn Med Assoc. 1996;89:85-6.

10. McKnight RH, Koetke CA, Donnelly C. Familial clusters of green tobacco sickness. J Agromed. 1996;3:51-9. 
11. Curwin BD, Hein MJ, Sanderson WT, Nishioka MG, Buhler W. Nicotine exposure and decontamination on tobacco harvesters' hands. Ann Occup Hyg. 2005;49:407-3.

12. Ghosh SK, Parikh JR, Gokani VN, Rao MN, Kashyap SK, Chatterjee SK. Studies on occupational health problems in agricultural tobacco workers. J SOC Occup Med. 1980; 29: 113-7.

13. Department of Agriculture (US), Foreign Agricultural Service. World's leading unmanufactured tobacco producing, trading and consuming countries. (Online PDF). Available from: http://www.fas.usda.gov/tobacco/circular/2004/082 004/TBL1.PDF. [Last Accessed on $17^{\text {th }}$ July, 2021] 14. McKnight RH, Kryscio RJ, Mays JR, et al. Spatial and temporal clustering of an occupational poisoning: the example of green tobacco sickness. Stat Med. 1996;15:747-57.

Source of support: Nil, Conflict of interest: None declared

Cite this article as:

Bharti P, Prerna, Rana R, Saini G, Neeraj. Green Tobacco Sickness: A Review. Int Healthc Res

J. 2021;5(9):RV6-RV8. https://doi.org/10.26440/IHRJ/0509.12458

\section{AUTHOR AFFILIATIONS: (*Corresponding Author)}

\section{Junior Residents, Department of Dentistry, UCMS and GTB Hospital, Dilshad Garden, Delhi-110095}

Contact Corresponding Author At: bhartipuja[at]gmail[dot]com 